\title{
CAR'TILAGE OR BONE INDUCTION BY ARTICULAR CARTILAGE
}

\author{
Observations with Radioisotope Labelling Techniques
}

\author{
Marshall R. Urist and Thompson Adams, \\ Los Angeles, California, United States of America \\ From the Bone Research Laboratory, Division of Orthopaedics, Department of Surgery, \\ School of Medicine, University of California, Los Angeles
}

This is a report of some new observations on cartilage and bone induction in post-foetal life. Several hundred embryonic and post-foetal induction systems have been described in the literature on cell and organ differentiation (Jacobson 1966), but few have advanced present knowledge of skeletal tissue morphogenesis, and none has noted the two separate pathways of development in transplants of articular cartilage. Urist and McLean (1952) observed that full-thickness transplants of homogenous articular cartilage from young rats induced formation of bone tissue in the anterior chamber of the eye. Using the same laboratory technique, experiments to be presented in this communication will demonstrate that the gliding surface of articular cartilage induces only fibrous tissue or hyaline cartilage formation, whereas the epiphysial surface of a growing young rat will induce bone formation. The transplants will consist of cells and matrix labelled with radioactive isotopes in young and old, living and dead, split-thickness and full-thickness isogenous articular cartilage. The results will suggest that modulating ${ }^{3} \mathrm{H}$-thymidine-labelled chondrocytes may act as inducing cells, and that ${ }^{3} \mathrm{H}$-glycine-latelled or ${ }^{35} \mathrm{~S}$-labelled cartilage matrix may act as inducing surfaces for osteogenesis.

\section{MATERIALS AND METHODS}

Samples of articular cartilage were obtained from the knee joints of three- to four-week-old immature rats, Lewis inbred strain (Microbiological Laboratory Association), 100 to 150 grammes in weight, of mixed sexes. Thin translucent slices were cut in the coronal plane with a razor blade and with the aid of a dissecting microscope. Special care was taken to exclude the underlying bony articular cortex. Very thin slices were cut to isolate the flattened small chondrocytes and the underlying zone of cell generation of the articular surface. Thicker slices were cut to include both the cells of articular surface and the round and hypertrophic cells of the epiphysial side of the articular cartilage. The slices were cut in the vertical plane into two parts-one part was fixed in formalin and stained in haematoxylin, eosin and azure II to determine the thickness and cell types; the other part was trimmed to fit into the bore of a seventeen-gauge needle to inject into the anterior chamber of the eye of an adult isogenous rat of the Lewis inbred strain.

The above experiments were also performed on thin split-thickness and full-thickness transplants of articular cartilage of senile rats twenty-four to thirty months of age.

The radioisotope-labelling procedures and the design of experiments with over 200 tissue transplants will be described with a running account of the results. Autoradiographs were prepared by methods described in previous reports (Young 1963, 1964; Urist, Wallace and Adams 1965).

\section{RESULTS}

After transplantation to the anterior chamber of the eye the chondrocytes in fresh slices of isogenous cartilage survived and produced a variety of cell reactions, transformations and inductive processes. The transplant increased only very little in volume; resorption and 
remodelling began within a few weeks, and new bone formation appeared soon afterwards. Whether the transplant produced bone, however, was determined by its composition-that is, whether it contained germinal cells of the deeper layer. If it contained germinal layer cells

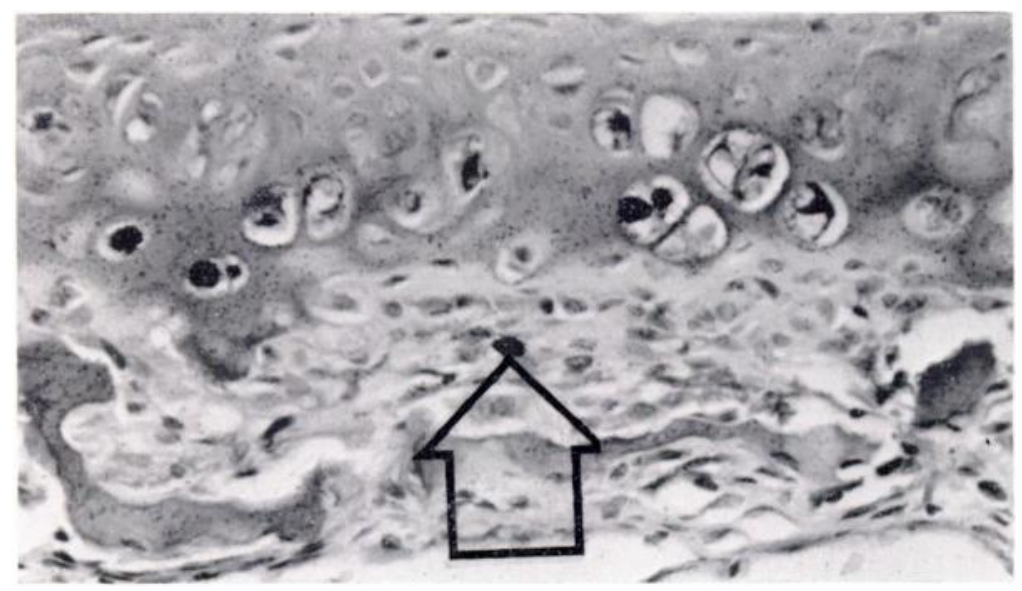

FIG. 1

Autoradiograph showing transplant of full thickness of articular cartilage after four weeks in the anterior chamber of the eye. The cells of the gliding surface (top) are relatively unaffected by the new environment, while the cells of the middle layer are swollen and pale-staining. Hypertrophic cartilage with ${ }^{3} \mathrm{H}$-thymidine-labelled nuclei and subjacent osteogenic connective tissue cells are shown at the bottom of the picture. The cell indicated by the arrow is a labelled chondrocyte divested of capsule and matrix, and free in the centre of a pool of proliferating connective tissue cells. (Periodic acid-Schiff and haematoxylin approximately $\because \mathbf{2 0 0}$.)

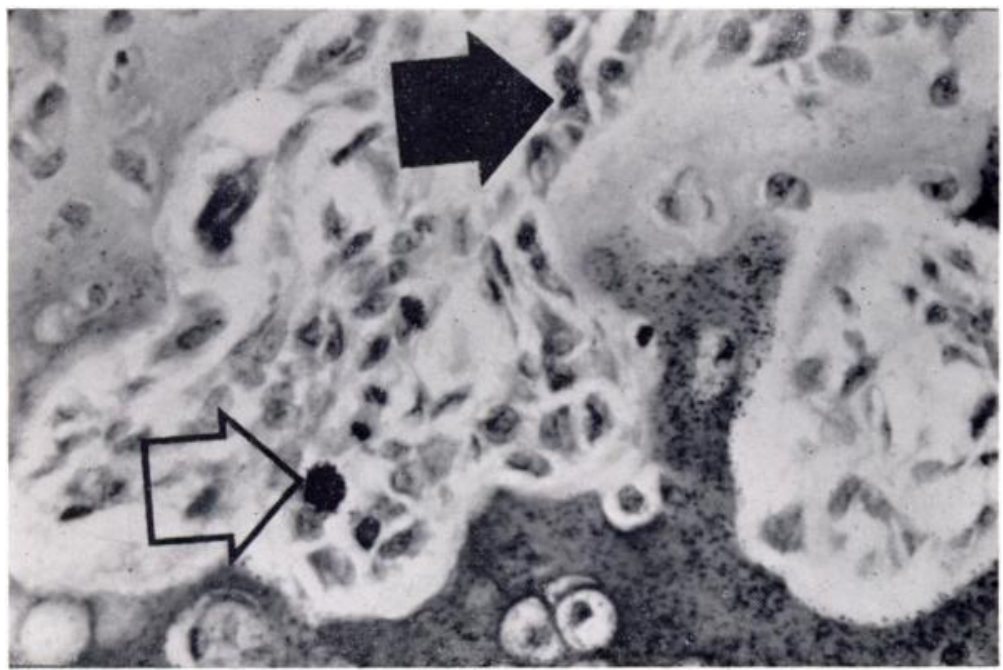

FIG. 2

Autoradiograph with ${ }^{3} \mathrm{H}$-glycine to label the cartilage matrix and ${ }^{3} \mathrm{H}$-thymidine to label the cartilage cells of the donor, showing a pool of osteogenic connective tissue cells with a chondrocyte nucleus free in the middle (transparent arrow).

The black arrow indicates an area of differentiation of osteoblasts and new bone. (Periodic acid-Schiff, haematoxylin and eosin, $\because 400$.)

(epiphysial), the chondrocytes swelled, dissolved their capsules and intercellular matrix. coalesced and became accessible to ingrowing capillaries from the host bed (Fig. 1). This process always began on the cut surface or epiphysial side, never appeared on the smooth

VOL. $50 \mathrm{~B}$, NO. 1, FerRUARY 1968 
surface of the articular side of the transplant, and led to the formation of excavation chambers (Fig. 2). Although the excavation of the cartilage was always associated with the ingrowth of blood vessels from the iris and proliferating tissues of the host bed, chondrolysis was a preliminary if not initial reaction. As shown in Table I, the small chondrocytes of the gliding

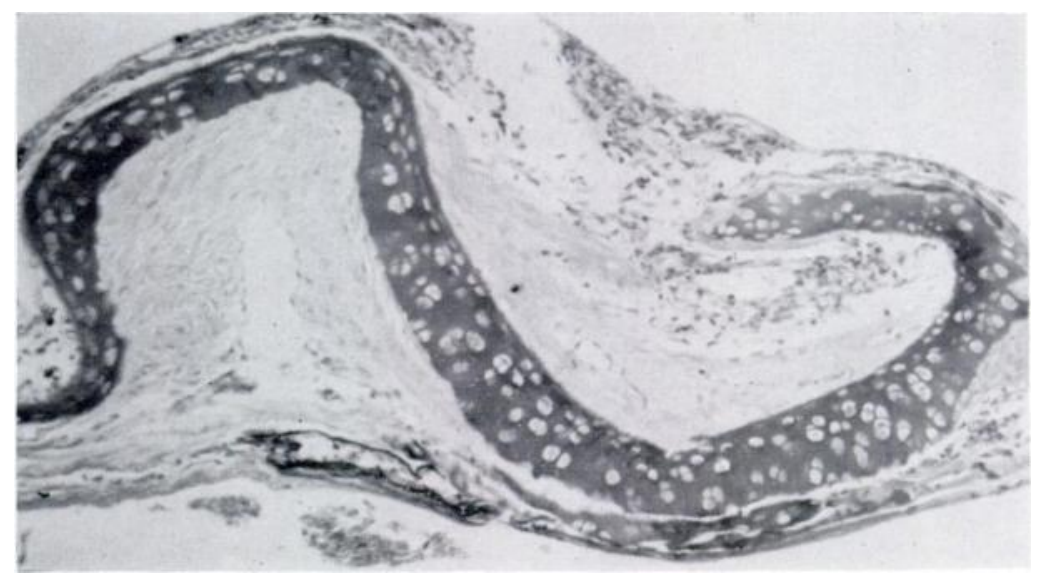

FiG. 3

Photomicrograph showing thin slice of the gliding surface of the articular cartilage after six weeks in the anterior chamber of the eye. The transplant is enveloped in a capsule of fibrous connective tissue and does not produce excavation chambers or osteogenesis. (Periodic acid-Schiff and haematoxylin stain, $\times 50$.)

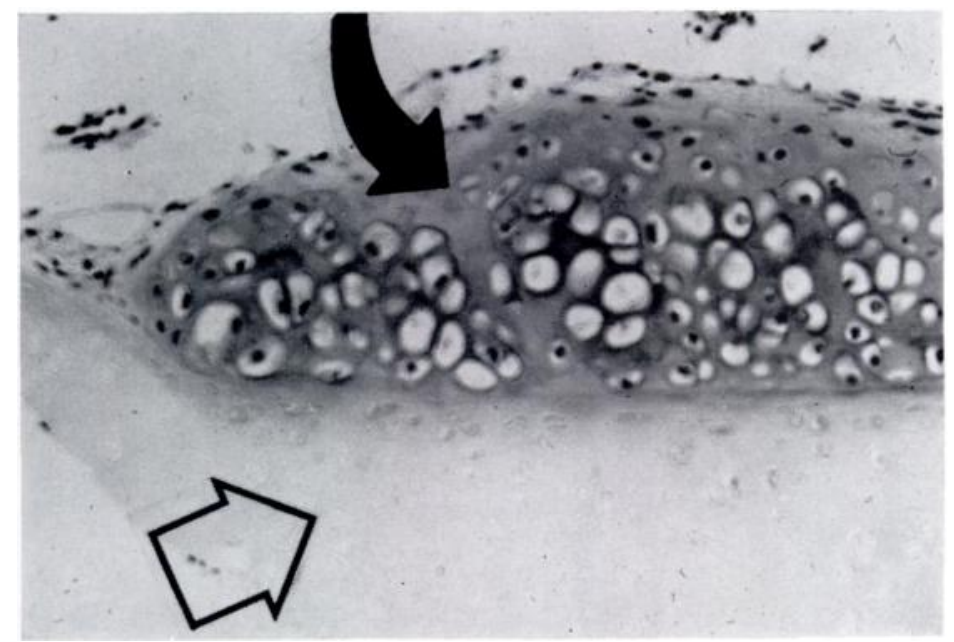

FIG. 4

Photomicrograph showing a thick slice of articular cartilage extracted with $0.6 \mathrm{~N}$ hydrochloric acid after ten weeks in the eye. The implant is palestaining, acellular and without excavation chambers or ingrowing vascular tissue (transparent arrow). The gliding surface, however, is covered by a nodule of new hyaline cartilage (black arrow) produced presumably by autoinduction. In this instance both the inducing and responding cells must have come from the host. (Haematoxylin, eosin and azure stain, $\times 40$.)

surface of the articular cartilage induced formation only of fibrous tissue in nearly all instances and no new bone (Fig. 3). Cells from the deeper layers (Mankin's Zone B) produced new bone in over 90 per cent of the samples of fresh viable tissue. Dead cells, either cryolysed or extracted with $0.6 \mathrm{~N}$ hydrochloric acid, induced scar formation. In a few instances, however, 
TABLE I

End Products of Transplants of Articular Cartilage to Anterior Chamber of the Eye

\begin{tabular}{|c|c|c|c|c|}
\hline \multirow[b]{2}{*}{ Composition, thickness and source of transplant } & \multirow[b]{2}{*}{$\begin{array}{l}\text { Number of } \\
\text { transfers }\end{array}$} & \multicolumn{3}{|c|}{ End preduct (per cent) } \\
\hline & & $\begin{array}{l}\text { Fibrous } \\
\text { tissue only }\end{array}$ & $\begin{array}{l}\text { Hyaline } \\
\text { cartilage }\end{array}$ & $\begin{array}{c}\text { New hyaline } \\
\text { cartilage } \\
\text { or bone }\end{array}$ \\
\hline $\begin{array}{l}\text { Gliding surface, thin split thickness, immature donor, viable } \\
\text { tissue. }\end{array}$ & 30 & 94 & $6^{*}$ & 0 \\
\hline $\begin{array}{l}\text { Same as above, except decalcified in hydrochloric acid, and } \\
\text { dead }\end{array}$ & 20 & 90 & $10^{*}$ & 0 \\
\hline $\begin{array}{l}\text { Whole thickness including epiphysial germinal layer } \\
\text { chondrocytes, immature donor, viable tissue . }\end{array}$ & 70 & 4 & 0 & $96 \dagger$ \\
\hline $\begin{array}{l}\text { Same as above, except decalcified in hydrochloric acid, and } \\
\text { dead . }\end{array}$ & 30 & 70 & $20 *$ & $10^{*}$ \\
\hline Whole thickness tissue, devitalised by cryolysis & 40 & 96 & 0 & $4^{*}$ \\
\hline Gliding surface, thin split thickness, senile adult rat & 10 & 100 & 0 & 0 \\
\hline Whole thickness, senile adult rat & 20 & 95 & 5 & 0 \\
\hline
\end{tabular}

* Only after a lag period of two to three months; no appreciable uptake of ${ }^{35} \mathrm{~S}$ in vitro before implantation in the eye.

† Within less than four weeks after transplantation.

after several months, both the processes of resorption and the initiation of osteogenesis were impeded. As a delayed reaction, there was induction of formation of hyaline cartilage (Fig. 4).

In thirty transplants of articular cartilage from senile rats twenty-four to thirty months of age, there was induction only of fibrous scar in 95 per cent; new cartilage formation appeared in addition in 5 per cent of the implants examined during periods of four to twelve weeks in the anterior chamber of the eye.

Radioactive sulphur-labelled transplants-In an effort to visualise the fate of mucoproteins in the matrix of non-viable and viable transplants samples of whole-thickness articular cartilage were labelled with ${ }^{35} \mathrm{~S}$ in various ways. Twenty-two transplants were examined at intervals of one and four weeks after the operation, and fifteen hours after each host was injected intraperitoneally with 0.5 millilitre of radioactive sodium sulphate in Tyrode's solution, 1 microcurie per gramme of rat weight; specific activity, $188 \mathrm{c} / \mathrm{mM}$. The results demonstrated that the chondrocytes in the deep layer of the articular cartilage were able to incorporate large amounts of ${ }^{35} \mathrm{~S}$ into the matrix, presumably through the process of synthesis of sulphated protein polysaccharides, including large amounts of chondroitin sulphate. Squamous chondrocytes of the gliding surface and the vesiculated hypertrophic cells on the exposed, cut surface, of the epiphysial side of the articular cartilage, incorporated only very small amounts.

Excavation chambers and deposits of new bone appeared between three and four weeks after the operation. As in normal endochondral ossification in epiphysial cartilage, there was replacement of hypertrophic cartilage and substitution with connective tissue cells and capillaries. In this process the number of cartilage cells that would secrete matrix and incorporate ${ }^{35} \mathrm{~S}$ into the intercellular substance decreased rapidly. At the end of eight weeks the labelled matrix was almost entirely replaced with unlabelled matrix of new bone and bone marrow, and only a few flattened chondrocytes remained from the articular surface of the original transplant.

Twenty-six transplants were labelled with ${ }^{35} \mathrm{~S}$ by an intra-articular injection into the knee of each donor with $0 \cdot 1$ millilitre of radioactive sodium sulphate $(100$ microcuries; specific activity $188 \mathrm{c} / \mathrm{mM}$ ) fifteen hours before transplantation. The host rats were killed and the

VOL. 50 B, NO. 1, FEBRUARY 1968 
implants were recovered between zero and four weeks after the operation. Autoradiographs showed ${ }^{35}$ S activity chiefly in the intercellular substance (Fig. 5). Grain counts demonstrated that the implants lost approximately 30 per cent of the radioactivity in two weeks, 50 per cent in three weeks (Fig. 6), and 80 per cent in four weeks. Chondrolysis, excavation chambers

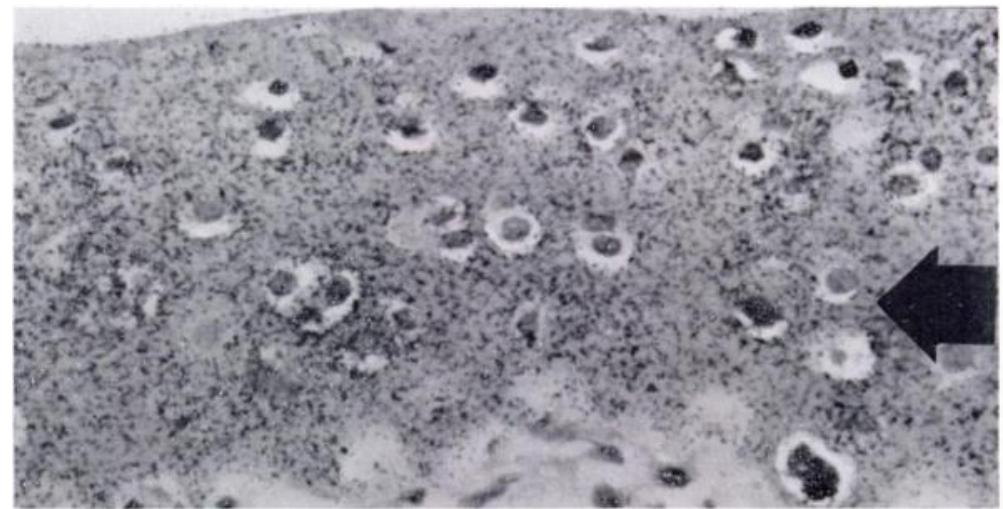

FIG. 5

Autoradiograph showing ${ }^{35} \mathrm{~S}$ radioactivity persisting in the intercellular substance after two weeks in the anterior chamber of the eye. The radioisotope was administered by intra-articular injection of the donor, fifteen hours before transplantation. The grain count is highest around the deep or epiphysial germinal layer of cells. (Periodic acid-Schiff and haematoxylin, approximately 150.)

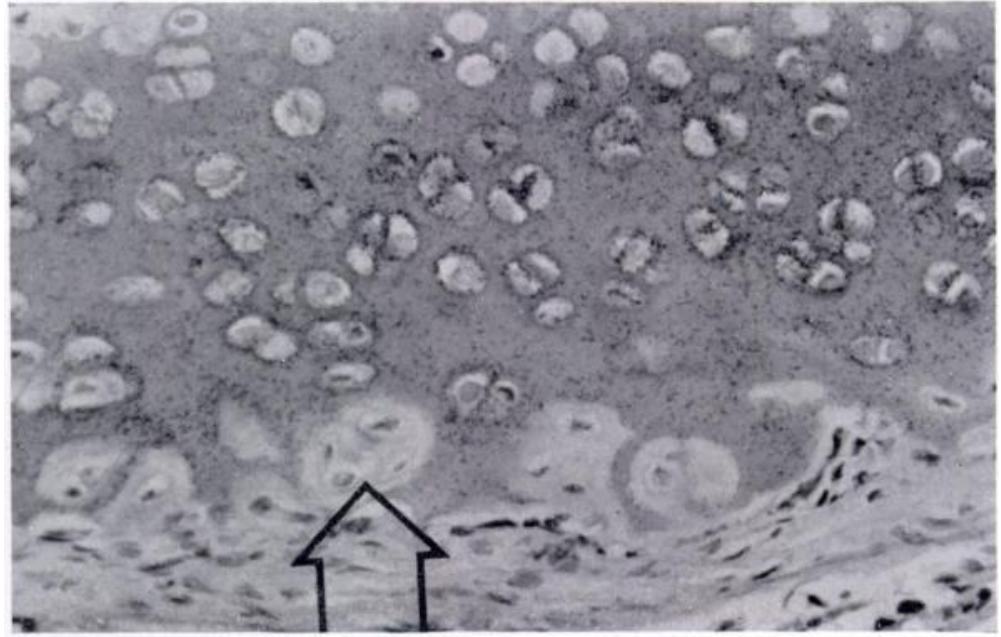

FIG. 6

Autoradiograph of ${ }^{35} \mathrm{~S}$-labelled articular cartilage after three weeks in the cye, showing reduction of over 50 per cent of the original amount of radioactivity. Note chondrolysis-dissolution of the capsule and ${ }^{35} \mathrm{~S}$-labelled matrix surrounding the cells of the deep layer of articular cartilage (transparent arrow). New ingrowing perivascular connective tissue cells of the host appear at the bottom of the picture. (Periodic acid-Schiff, haematoxylin and eosin, approximately 200.)

and bone formation appeared after three weeks, but there was no visible translocation of ${ }^{35} \mathrm{~S}$ activity from the resorbing, labelled, old cartilage matrix of the donor to the new bone matrix deposited by the host.

The relationship between radioisotope uptake, cell viability and the early appearance of osteogenesis was investigated in nine samples of fresh donor tissue and nine samples of thrice 
frozen and thawed tissue. The donor tissue was simply exposed to the solutions of ${ }^{3} \mathrm{~S}$ radioactive sodium sulphate, in homologous serum in vitro for one hour, and prepared for radioautographic examination immediately afterwards. The uptake of ${ }^{35} \mathrm{~S}$ was high only in the fresh (Fig. 7), and generally very low or nil in the cryolysed cartilage. Thus, cryolysis reduced or destroyed the cell viability that is necessary for high uptake of ${ }^{33} \mathrm{~S}$. It also destroyed the cellular activity of the donor tissue that is necessary for early onset of osteogenesis (less than three weeks after transplantation). As a rule, devitalised cartilage produced chondrogenesis or osteogenesis by autoinduction only after several months and, even then, the incidence of positive results was very low: the end-product was very scanty in amount, and the end-product was histotypic and not organotypic (Table I, line 5).

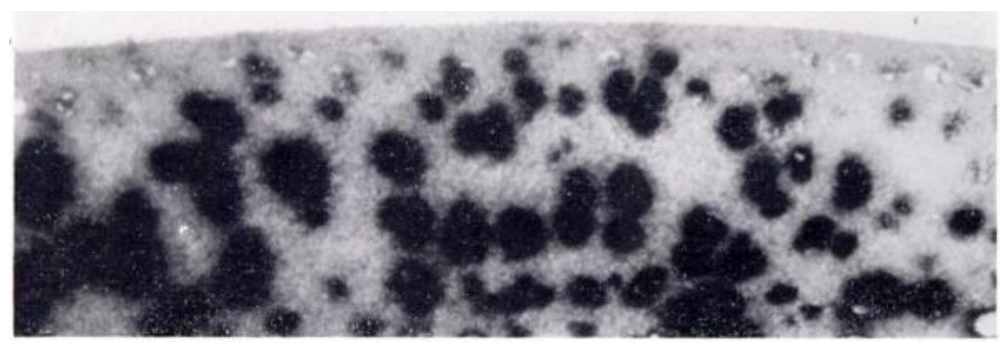

FIG. 7

Autoradiograph of a slice of articular cartilage following exposure of the donor cells to a solution of ${ }^{35} \mathrm{~S}$ (sodium sulphate in Tyrode's solution) in vitro for one hour. The radioactivity is concentrated first in the cytoplasm and capsule of the chondrocytes of the middle and deep layers, and later transferred with synthesis of protein polysaccharides to the matrix. The cells of the gliding surface are relatively inactive in protein polysaccharide synthesis and show little or no ${ }^{35} \mathrm{~S}$ radioactivity. (Periodic acid-Schiff and haematoxylin, approximately $\cdot 100$.)

Effects of papain and cortisone-In order to investigate the possible role of the mucoproteinous constituents of the intercellular matrix of cartilage in bone induction the donor was treated with an intra-articular injection of 5 milligrams of crude papain (Africana papaya, Cal. Biochem., Los Angeles) in Tyrode's solution into the knee joint. Fifteen slices of full-thickness, translucent, bone-free articular cartilage obtained from six rats sixteen hours after the injection were divided into two parts. Figures 8 and 9 show the appearance of the donor tissue in control samples in situ before transplantation. One part was stained with Alcian blue to determine the effect that papain had had on the mucoprotein of the matrix; papain removed the Alcian blue staining substances from the superficial two-thirds of the thickness of the cartilage. The second part was transplanted to the eye. The host rats were treated with intramuscular injections of cortisone acetate, 35 milligrams per day, to suppress re-formation of the papain-labile components of the matrix, and possibly also any other proteinous substances that might be essential for bone induction. Thirteen transplants, untreated with papain, were implanted into the anterior chamber of the eye of cortisone-treated host rats for controls. The results suggested that neither papain nor cortisone, nor the two together, prevented bone induction. Cortisone alone, however, retarded proliferation of the cells and new capillaries that were active in the formation of excavation chambers and the process of differentiation of osteoprogenitor cells; it completely suppressed differentiation of cells of myelogenetic series; it prevented the induced cells from organising into an ossicle. The inductive reactions, therefore, did not go to completion. Instead of culminating in the formation of an ossicle with a cortex and a narrow cavity, it produced only masses of fibroblasts, large amounts of poorly staining, unabsorbed matrix and some scanty deposits of lamellar bone (Figs. 10 and 11).

Cell interrelationships observed after treatment of the host with ${ }^{3} \mathrm{H}$-thymidine-Table II illustrates the results of experiments in which full-thickness slices of fresh articular cartilage

VOL. 50 B, NO. 1, FEBRUARY 1968 
were transplanted into the anterior chamber of the eye of host rats injected intraperitoneally with 0.5 millilitre of ${ }^{3} \mathrm{H}$-thymidine ( 1 microcurie per gramme of body weight; specific activity, $5 \mathrm{c} / \mathrm{mM}$ ). The average dose was approximately 125 microcuries per rat and the injection was given fifteen hours before killing at regular intervals between one and four weeks in order to label the nuclei of cells that were synthesising DNA in preparation for mitotic division. The object was to determine whether chondrocytes would divide, and at what stage of development

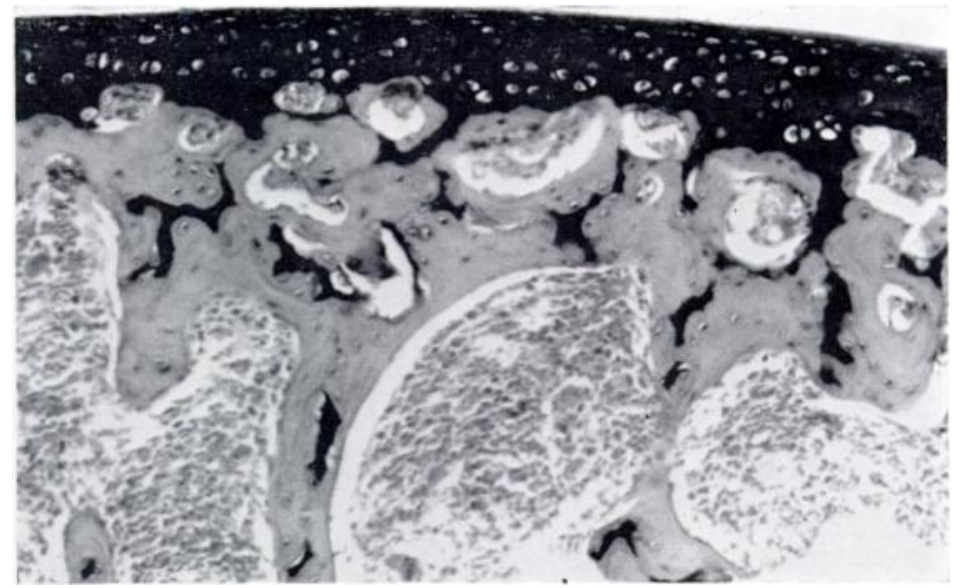

Fig. 8

Photomicrograph of articular cartilage and subchondral spongiosa of normal knee joint. (Alcian blue stain for protein polysaccharides, 100 .)

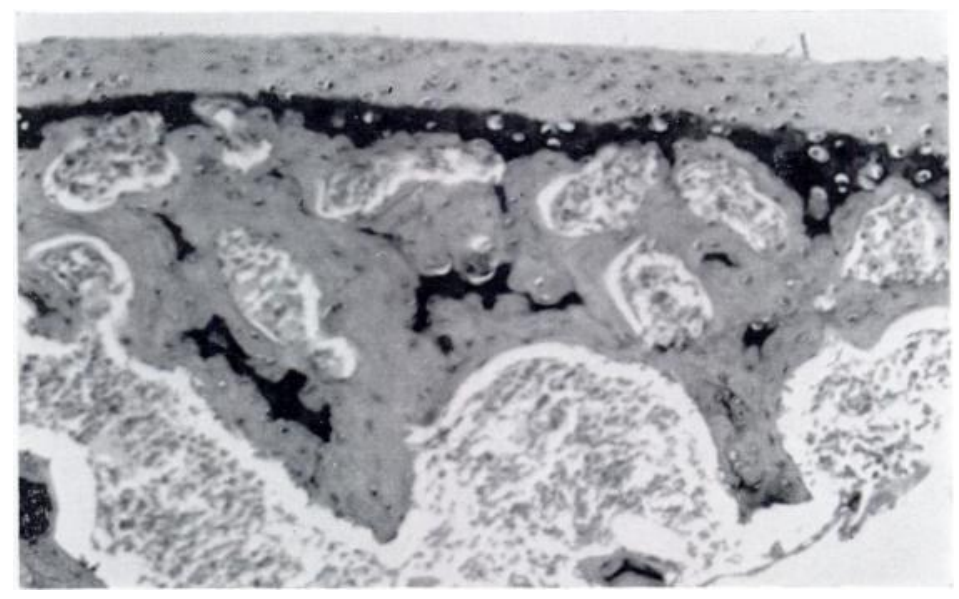

FIG. 9

Photomicrograph of articular cartilage of knee joint injected with 5 milligrams of papain, showing degradation of Alcian blue staining mucoproteinous components of the intercellular matrix. The action of the enzyme did not penetrate the deep layer of cells of the articular cartilage or reach the remnants of unabsorbed matrix in the subchondral spongiosa. $(\times 100$.

the cell was able to induce bone formation. The cells were classified as round, hypertrophic and squamous, according to location and form, and the percentage of labelled cells was noted in each category. The results suggested that at all intervals between one and four weeks the labelled cells were chiefly the paired and round chondrocytes in the deep layer on the epiphysial side of the articular cartilage. 


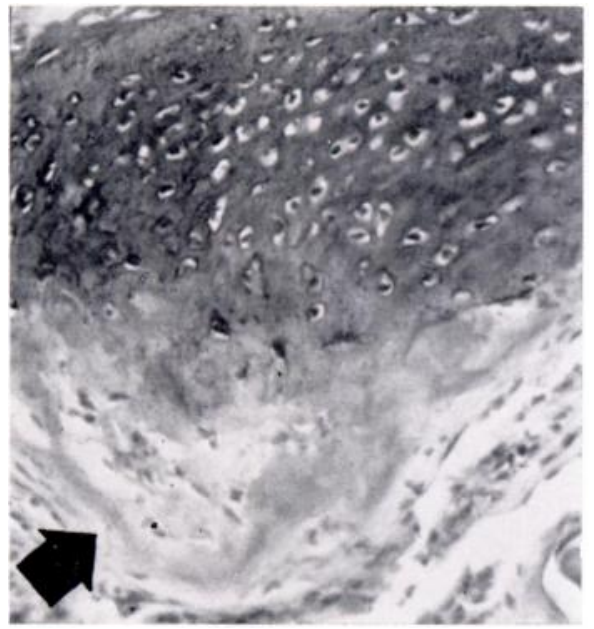

Fig. 10

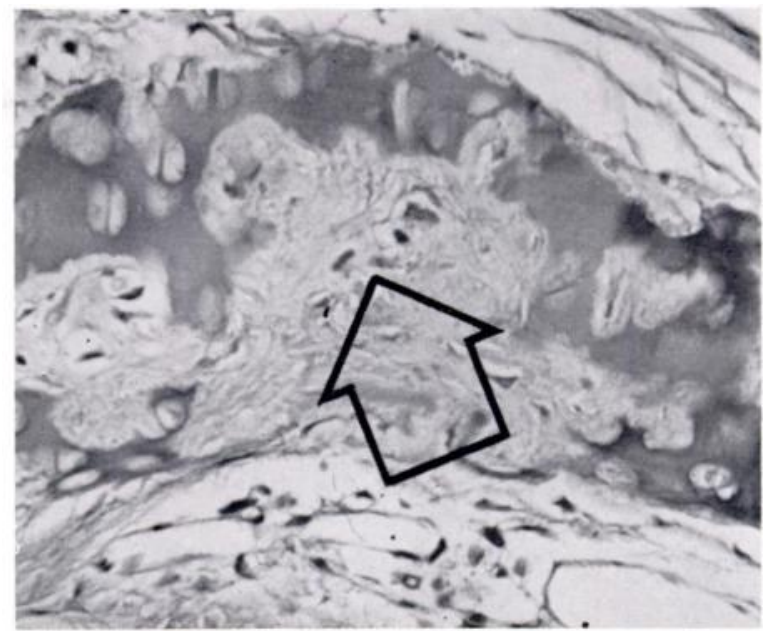

Fig. 11

Figure 10-Photomicrograph of transplant of papain-treated articular cartilage, after four weeks in the eye of a rat treated with cortisone acetate to suppress resynthesis of the protein polysaccharides of the matrix. The area indicated by the arrow consists of fibrous tissue and a scanty deposit of new bone. (Alcian blue, $\times 100$.) Figure 11-Photomicrograph of an isogenous papainised transplant after six weeks in the eye of a litter mate treated with cortisone the same as the one referred to in Figure 10. The excavation chambers indicated by the transparent arrow are filled with connective tissue, osteogenetic cells, but there are only scanty deposits of poorly developed lamellar bone. (Alcian blue, $\therefore 200$.)

In the course of time, and with replacement of the cartilage in the eye, the number of chondrocytes that were preparing to divide decreased rapidly from 2.78 to 0.21 per cent. The unpaired chondrocytes generally had grain counts over fifty, while the paired ones generally had grain counts under fifty. When the cells were classified according to location, the highest percentage of labelled cells were the round chondrocytes in the middle of the slice. The number

TABLE II

Fate of Chondrocytes in Transplants of Articluar Cartilage with Nuclei labelled with ${ }^{3} \mathrm{H}$-Thymidine and Matrix LABelled With ${ }^{3} \mathrm{H}$-GlyCine

\begin{tabular}{|c|c|c|c|c|c|c|}
\hline \multirow{3}{*}{$\begin{array}{l}\text { Number } \\
\text { of } \\
\text { implants }\end{array}$} & \multirow{3}{*}{$\begin{array}{l}\text { Days in } \\
\text { anterior } \\
\text { chamber }\end{array}$} & \multicolumn{5}{|c|}{ Distribution of labelled cells - chondrocytes } \\
\hline & & \multirow{2}{*}{$\begin{array}{c}\text { Total } \\
\text { counted }\end{array}$} & \multirow{2}{*}{$\begin{array}{c}\text { Number labelled } \\
\text { (percentage of } \\
\text { total) }\end{array}$} & \multicolumn{3}{|c|}{ Classification of cell types (percentage } \\
\hline & & & & Round & Hypertrophic & Squamous \\
\hline 7 & 14 & 26,267 & $331-(1 \cdot 26)$ & 93 & $4 \cdot 8$ & $2 \cdot 2$ \\
\hline 10 & 28 & 20,177 & $428-(2.12)$ & $89 \cdot 7$ & $9 \cdot 3$ & 1 \\
\hline 14 & 35 & 25,518 & $336-(1 \cdot 32)$ & $91 \cdot 4$ & $3 \cdot 8$ & $4 \cdot 8$ \\
\hline
\end{tabular}

of chondrocytes with grain counts under fifty did not change; there was no indication, therefore, that chondrocytes were dividing or developing either into squamous or into hypertrophic cells. Instead, some were liberated, free of capsule and matrix, and dispersed among a population of new cells that grew in from the host bed.

Activity of chondrocytes and the reaction of the intercellular matrix of donor observed with the aid of double-labelled transplants-Twenty immature rats, 100 grammes in weight, were each given intra-articular injections: 0.1 millilitre of ${ }^{3} \mathrm{H}$-thymidine $(1 \mathrm{microcurie} /$ millilitre; specific activity, $6.7 \mathrm{c} / \mathrm{m} M)$, followed four hours later by 0.1 millilitre of ${ }^{3} \mathrm{H}$-glycine $(1$ microcurie/ millilitre; specific activity, $200 \mathrm{mc} / \mathrm{mM}$ ), and concluded four hours later by another $0 \cdot 1$

VOL. $50 \mathrm{~B}$, NO. 1, FEBRUARY 1968 
millilitre of ${ }^{3} \mathrm{H}$-thymidine ( 1 microcurie/millilitre; specific activity, $5 \mathrm{c} / \mathrm{m} \mathrm{M}$ ) to label the donor tissue. The rats were killed and full-thickness slices of articular cartilage were transplanted seven hours after the last injection (fifteen hours after the first injection) into the anterior chamber of the eye. The transplants were recovered fourteen, twenty-eight and thirty-five days after the operation for preparation of autoradiographs.

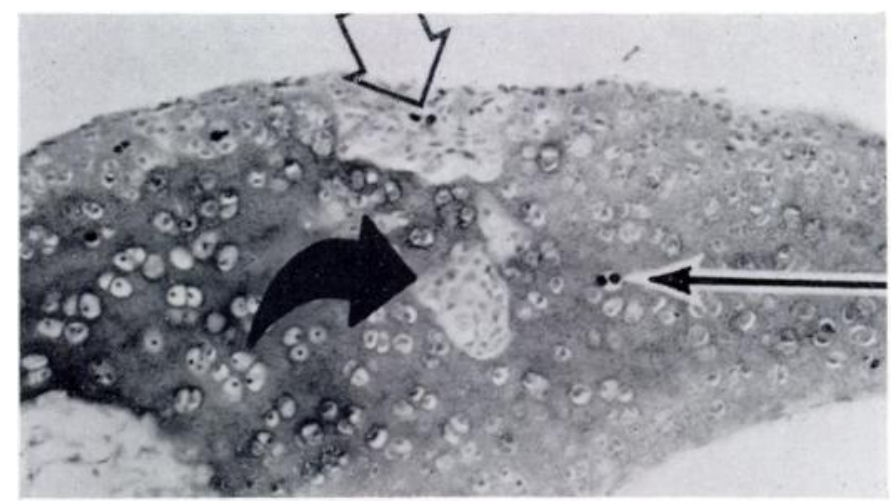

FIG. 12

Autoradiograph of transplant of articular cartilage three weeks after the operation. The donor tissue was obtained from a rat given intraarticular injections of ${ }^{3} \mathrm{H}$-thymidine to label nuclei of chondrocytes, and ${ }^{3} \mathrm{H}$-glycine to label the intercellular matrix. This oblique section shows 1) ${ }^{3} \mathrm{H}$-thymidine label in the nuclei of paired chondrocytes of the donor (white arrow) surrounded by dark ${ }^{3} \mathrm{H}$-glycine-labelled matrix; 2) light staining excavation chambers filled with unlabelled osteogenetic connective tissue (black arrow); 3) ${ }^{3} \mathrm{H}$-thymidine-labelled chondrocytes, divested of capsule, free in the middle of an excavation chamber (transparent arrow). (Periodic acid-Schiff and haematoxylin, 150.)

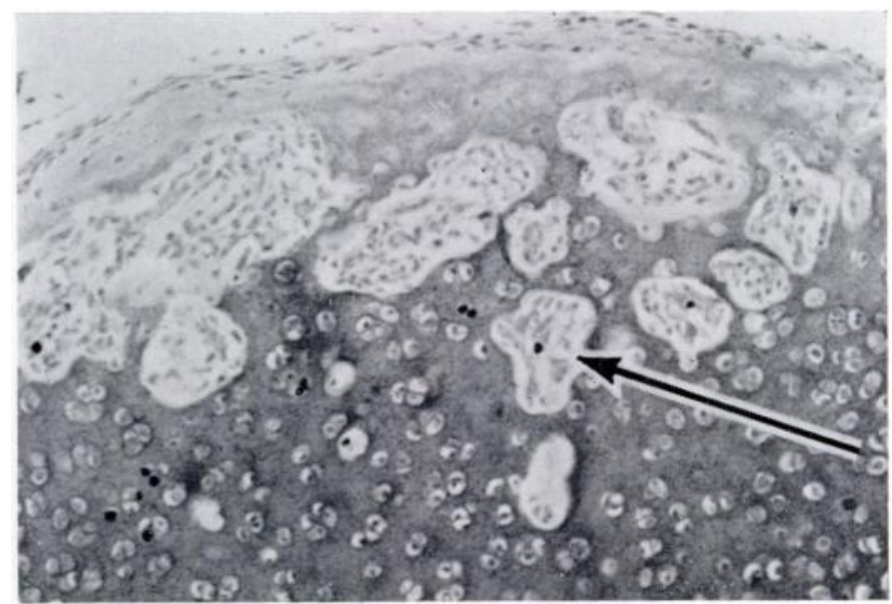

FIG. 13

Autoradiograph of a coronal or surface section of another part of transplant shown in Figure 12. Note the clear-cut differentiation between the ${ }^{3} \mathrm{H}$-glycine-labelled donor and the unlabelled osteogenetic connective tissue of the host. The nucleus of a modulating ${ }^{3} \mathrm{H}$-thymidine-labelled chondrocyte, free in the pool of osteogenetic connective tissue, is indicated by the arrow. (Periodic acid-Schiff and haematoxylin, $\times 150$.)

The transplants examined after two weeks in the eye showed labelling of the cartilage matrix with ${ }^{3} \mathrm{H}$-glycine, and the nuclei of the chondrocytes with ${ }^{3} \mathrm{H}$-thymidine; ${ }^{3} \mathrm{H}$-glycine was deposited chiefly as a diffuse deposit throughout the extracellular substance; ${ }^{3} \mathrm{H}$-thymidine, in contrast, was distributed chiefly in cell nuclei, and in nearly all instances in the round 
chondrocytes in the deep zone of cartilage cell proliferation (Mankin's Zone B), which was engaged in the process of endochondral ossification of the epiphysis. When the cells were classified and counted, as summarised in Table II, the label was in 93 per cent of the round cells beneath the surface, in only 4.8 per cent hypertrophic chondrocytes on the epiphysial side and in less than 2.2 per cent of the squamous or small flat chondrocytes (Mankin's Zone A) on the

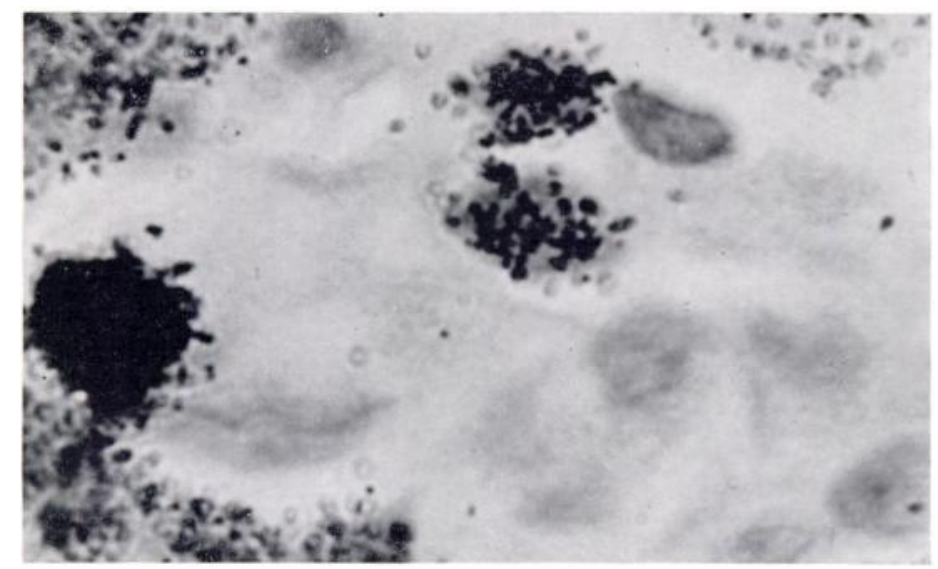

FIG. 14

Oil immersion view of labelled modulating chondrocytes, one with grain count over fifty (left), and two daughter cells with grain counts under fifty (right). The surrounding " $\mathrm{H}$-glycine-labelled matrix of the donor tissue is clearly differentiated from the unlabelled connective tissue cells of the host. (Periodic acid-Schiff and haematoxylin, $\because 2,000$.)

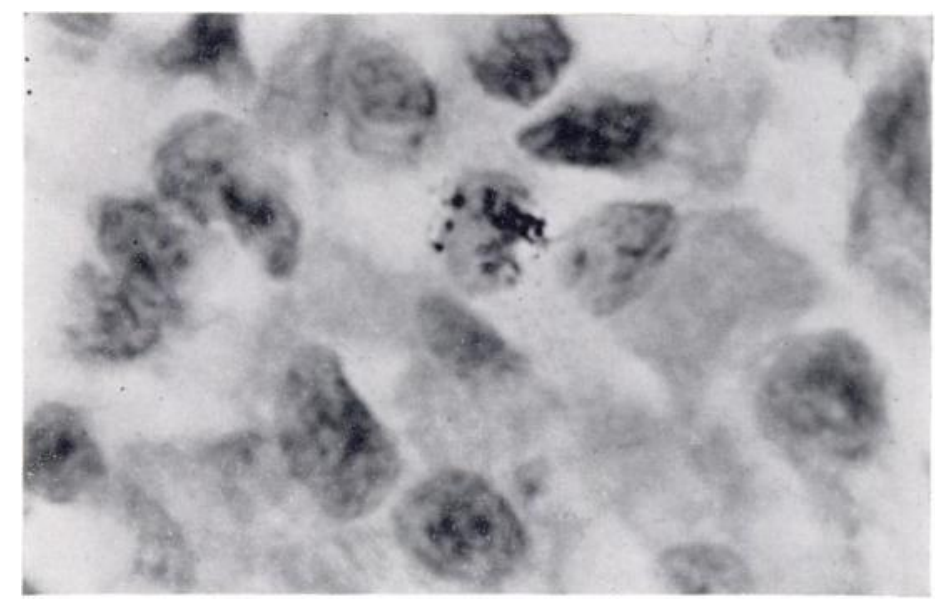

FIG. 15

Oil immersion view of the cells shown in Figure 14 following treatment of the preparation with Farmer's reducer solution to remove some of the silver grains from the emulsion, and expose the nuclei of the underlying cells. Some of the modulating labelled chondrocytes of the donor appear to be surviving and dividing in the centre of the pool of proliferating connective tissue cells of the host. (Periodic acid-Schiff and haematoxylin, $\times 2,000$.)

articular surface side of the transplant. Between two and seven weeks in the eye the distribution and relationship of the percentage of labelled cells in each class did not appear to change appreciably, and it was apparent that the chondrocytes ceased to develop or differentiate further; the round cells discounted their line of specialisation as cells of articular cartilage.

VOL. 50 B, NO. 1. FEBRUARY 1968 
Instead, the pathway of development of most of the labelled chondrocytes changed to induce osteogenesis. The process, as noted in Table III, took place in excavation chambers, formed by dissolution of cell capsules, by lysis of pericapsular matrix (chondrolysis) and by coalescence of adjacent chondrones or nests of cells. As shown in Figure $2,{ }^{3} \mathrm{H}$-glycine-labelled components disappear from the intercellular matrix, presumably by proteolytic and collagenolytic activity

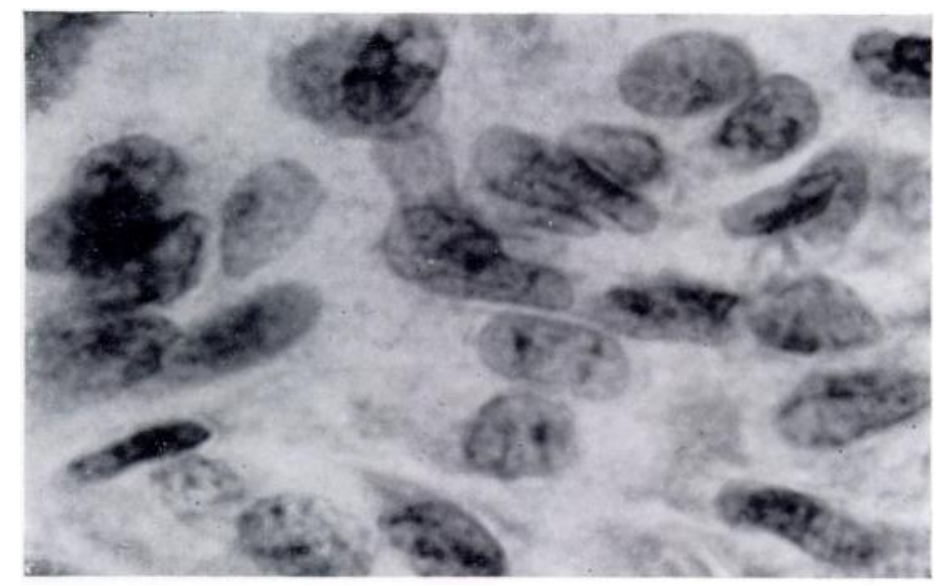

Fig. 16

Oil immersion view of the mixture of proliferating donor and host cells in the centre of an excavation chamber. Differing from the picture shown in Figures 14 and 15, the rocus is not on the emulsion but on the underlying cells, to demonstrate that the nuclei are normal in appearance. $(\times 2,000$.)

of Zone B chondrocytes. The hypertrophic vesiculated chondrocytes did not react similarly but appeared to degenerate the same as in situ during endochondral ossification. Articular surface chondrocytes, as shown in Figures 12 to 16, remained as specialised cells, and without any appreciable alteration in their extracellular substances or fibres.

Between three and four weeks after transplantation, immediately after the above-described two incidents-dissolution of the intercellular matrix between young dividing chondrocytes and degeneration of vesiculated hypertrophic chondrocytes-there was ingrowth of new

TABLE III

Fate of Cells of Articular Cartilage Double labelled with ${ }^{3} \mathrm{H}$-Thymidine and ${ }^{3} \mathrm{H}$-Glycine at VARIOUS INTERVALS Before AND AFTER BONE INDUCTION

\begin{tabular}{|ccccccc}
\hline $\begin{array}{c}\text { Number } \\
\text { of } \\
\text { implants }\end{array}$ & $\begin{array}{c}\text { Days in } \\
\text { anterior } \\
\text { chamber }\end{array}$ & $\begin{array}{c}\text { Total } \\
\text { counted }\end{array}$ & $\begin{array}{c}\text { Number labelled } \\
\text { (percentage of } \\
\text { total) }\end{array}$ & $\begin{array}{c}\text { More } \\
\text { than } \\
\text { 50 grains }\end{array}$ & $\begin{array}{c}\text { Less } \\
\text { than } \\
\text { 50 grains }\end{array}$ & $\begin{array}{c}\text { Average } \\
\text { grain } \\
\text { count }\end{array}$ \\
\hline 7 & 14 & 1,130 & $7 \cdot 7$ & 1 & 87 & $10 \cdot 6$ \\
\hline 10 & 28 & 16,684 & $2 \cdot 4$ & 42 & 351 & $14 \cdot 3$ \\
\hline 14 & 35 & 24,770 & $1 \cdot 1$ & 35 & 240 & $10 \cdot 7$ \\
\hline
\end{tabular}

capillaries and young connective tissue cells from the host bed. The interaction of the proliferating cells of the donor and the host capillaries produced excavation chambers in the transplanted articular cartilage, as shown in Figures 12 to 16 . Inasmuch as 1 to 2 per cent of the original cells of the donor were labelled with ${ }^{3} \mathrm{H}$-thymidine, and some of the cells that filled the excavation chambers were descendants of the cells of the germinal layer of articular 
cartilage, it was possible to determine the pathway of further development of the labelled donor cells. The percentages of labelled cells in excavation chambers at two, four and seven weeks after transplantation were calculated, as shown in Table III. There was a very small number of heavily labelled cells (those with grain counts greater than fifty) and a large number of lightly labelled cells (those with grain counts under fifty). The average grain counts of the latter were 14.3 to $10 \cdot 6$, which suggested that they could have been cells that had undergone modulation and one or more mitotic divisions. The total population of labelled cells, despite the increase in the number of cells with low grain counts, decreased in the interval between two and seven weeks in the eye. Thus, the influx of cells from the host was massive and there was enormous dilution of the relatively small population of cells produced by mitotic division of chondrocytes of the germinal layer (Zone B) of the donor tissue.

The possibility that the labelled nuclei in the mass of rapidly multiplying cells in the middle of an excavation chamber were simply degenerating, or dead, and not modulating cells, was excluded by the following experiment. Several sections, which had heavily labelled cells in the middle of an excavation chamber, were treated by topical application of Farmer's reducer solution (Kodak Co.) to remove 90 per cent or more of the silver grains from the emulsion and disclose the structure of the chromosomes. As shown in Figures 5 to 7 , the nuclei were relatively large, not pyknotic, and had the morphological characteristics of chromatin granules of normally-staining, rapidly-dividing, young connective tissue cells.

Between three and four weeks after transplantation, osteoblasts and osteocytes appeared adjacent to and inside lamellae of bone, newly deposited on the walls of the excavation chambers. The percentage of these cells that were labelled was low- 0.13 -and the average grain count was very low-sometimes only 9.9 (Table IV). Seven weeks after transplantation there was further reduction in the percentage of labelled cells, but no significant reduction in the average grain count. These results suggested that some of the new bone cells were descendants of the progeny of chondrocytes, originally in the Zone B or the epiphysial layer of articular cartilage. Some of the young chondrocytes, divested of their capsule and

TABLE IV

Fate of Cells of Transplants of Articular Cartilage Double Labelled with ${ }^{3}$ H-Thymidine and ${ }^{3}$ H-Glycine

\begin{tabular}{|c|c|c|c|c|c|c|c|}
\hline $\begin{array}{c}\text { Number } \\
\text { of } \\
\text { implants }\end{array}$ & $\begin{array}{c}\text { Days in } \\
\text { anterior } \\
\text { chamber }\end{array}$ & $\begin{array}{c}\text { Total } \\
\text { counted }\end{array}$ & $\begin{array}{c}\text { Percentage } \\
\text { labelled }\end{array}$ & $\begin{array}{c}\text { Average } \\
\text { grain count }\end{array}$ & $\begin{array}{c}\text { Total } \\
\text { counted }\end{array}$ & $\begin{array}{c}\text { Number labelled (all 50 grains) } \\
\text { Total- } \\
\text { percentage }\end{array}$ & $\begin{array}{c}\text { Average } \\
\text { grain count }\end{array}$ \\
\hline 7 & 14 & 0 & 0 & 0 & 0 & 0 & 0 \\
\hline 10 & 28 & 6,788 & 0.13 & $7 \cdot 3$ & 5,239 & $34-(0 \cdot 6)$ & $10 \cdot 5$ \\
\hline 14 & 35 & 13,050 & 0.05 & $15 \cdot 2$ & 10,866 & $44-(0 \cdot 4)$ & $9 \cdot 9$ \\
\hline
\end{tabular}

extracellular matrix, apparently were able to dedifferentiate and redifferentiate (modulate) into osteoblasts. Modulating cells were relatively few in number and appeared to integrate with the general population of proliferating perivascular connective tissue cells that grow in from the host bed, but interaction of small modulating and large proliferating populations of cells produced the induction system for osteogenesis (Fig. 17).

In areas not connected with excavation chambers or sites of osteogenetic induction, the extracellular matrix of some of the chondrocytes reacted in an altogether different way. The matrix became fibrous and stained irregularly with periodic acid-Schiff reagent. This tissue subjectively resembled the chondro-osteoid seen in rachitic bone, or chondroid seen in the process of ossification of the deer's antler. In other areas, not connected either in any way

VOL. $50 \mathrm{~B}$, NO. 1, FEBRUARY 1968

0 
with osteogenetic tissue or capillary sprouts, there were nodules of unlabelled proliferating new hyaline cartilage cells. This tissue, therefore, must have arisen de novo by chondrogenetic induction of host cells. Chondroid formation by old cartilage cells of the donor differed from cartilage from new differentiating cells of the host by the presence of labelled nuclei only in

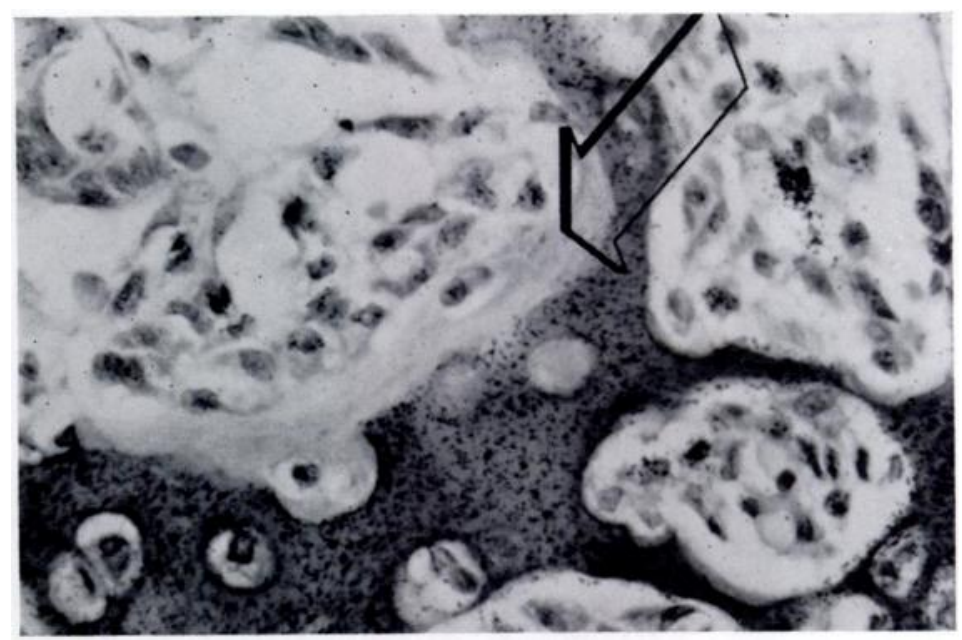

FIG. 17

Autoradiograph of articular cartilage after four weeks in the eye, showing retention of the ${ }^{3} \mathrm{H}$-glycine label in the matrix of the donor tissue. The new bone (arrow), produced by the interaction of the cells of the donor and the cells of the host, is unlabelled. Some of the osteoblasts and osteoprogenitor cells in the centre of the excavation chambers have labelled nuclei. (Periodic acid-Schiff and haematoxylin, $\times 400$.)

the former (Table V). The grain counts were always high (well over fifty) and the percentage of labelled nuclei did not decline during the period between two and seven weeks in the eye. These results indicated that, although it developed in a very small part of the transplant, chondroid was derived from transformation of the total structure, cells and matrix of the original transplant of articular cartilage.

TABLE V

Fate of Cells of Transplants of Articular Cartilage Double Labelled With ${ }^{3} \mathrm{H}$-Thymidine and ${ }^{3} \mathrm{H}$-Glycine, Excluding Excavation Chambers or Areas of Bone Induction

\begin{tabular}{|c|c|c|c|}
\hline $\begin{array}{c}\text { Number of } \\
\text { implants }\end{array}$ & $\begin{array}{c}\text { Days in } \\
\text { anterior } \\
\text { chamber }\end{array}$ & $\begin{array}{c}|c| \\
\text { Total } \\
\text { counted }\end{array}$ & $\begin{array}{c}\text { Number labelled-* } \\
\text { (percentage) }\end{array}$ \\
\hline 7 & 14 & 11,631 & $43-(0 \cdot 37)$ \\
\hline 10 & 28 & 3,990 & $37-(0 \cdot 93)$ \\
\hline 14 & 35 & 1,588 & $13-(0 \cdot 82)$ \\
\hline
\end{tabular}

* All labelled cells were heavy (more than 50 grains).

\section{DISCUSSION}

The development of the cells in two separate strata of articular cartilage was described by Mankin (1962a, 1963, 1964a) with the aid of ${ }^{3} \mathrm{H}$-thymidine-labelling techniques. DePalma, Sawyer and Hoffman (1962) performed experiments with ${ }^{35} \mathrm{~S}$ and reviewed the extensive 
literature on the question of survival of chondrocytes after transplantation. Our observations demonstrate survival of the germinal cells (especially those of the deep or epiphysial layers) and, in addition, report cell proliferation-but not along lines of development of articular cartilage. Mature chondrocytes, like mature osteocytes, do not undergo mitosis and, as noted by Mankin (1962b, 1963, 1964b), do not divide mitotically in adult life. Chondrocytes from immature growing individuals discontinue mitotic division and growth, following the injury of transplantation, but can survive to lyse matrix, escape into the host bed and adopt an entirely different line of specialisation. This is not altogether surprising when we consider that viable cartilage cells can be isolated by digestion of intercellular matrix with trypsin and collagenase then cultivated in tissue culture, and even observed in vitro to turn over ${ }^{35} \mathrm{~S}$, just as other connective tissue cells do, for a long period of time (Kawiak, Moskalewski and Darzynkiewicz 1965).

After transplantation the donor cells discontinue all further growth and development as articular cartilage. The germinal cells modulate, swarm or interact with proliferating perivascular cells of the host and enter into an induction system for osteogenesis. New bone develops in five stages which are continuous, overlapping and interrelated. In the initial or latent stage the transplant is unattached to the host bed and free floating in the aqueous humour from one to seven days; in the stage of envelopment between seven and eighteen days, host connective tissue cells and proliferating capillaries surround and grow into the transplant; disintegration of capsules and coalescence of chondrocytes to form nests or pools of liberated cells, dissolution of intercellular substance, ingrowth of capillaries from the host bed, differentiation of osteoprogenitor and chondroprogenitor cells occurs between eighteen and twenty-eight days in the stage of resorption and remodelling; osteogenesis occurs in the fourth stage, between twenty-eight and thirty-five days, from differentiation and osteoprogenitor cells into osteoblasts, and deposition of new bone inside excavation chambers, or on the walls of remnants of cartilage matrix; organogenesis occurs in the final stage by means of internal remodelling of new bone and cartilage, differentiation of new haematopoietic bone marrow, and formation of a shell of compact cortical bone, between thirty-six and fifty-six days after the operation. The structural organisation of the end-product of organogenesis resembles that of an osteophyte from an osteoarthritic joint, or that of a loose body from osteochondromatosis (Figs. 18 and 19).

The degree of specialisation of the cartilage cell appears to determine its competence for induction. When the transplant is cut very thin to include only flattened small cells, specialised to perform the function of the gliding surface of the articular surface [Mankin's Zone A], it does not induce osteogenesis; it produces neither resorption, nor modulation, nor excavation chambers, nor new bone. Instead, after three weeks its effect in most instances is to induce the formation only of fibrous connective tissue, or after twelve weeks in a few instances to induce the formation of a nodule of hyaline cartilage.

Only a very small part of every transplant showed evidence of bone formation by chondroid metaplasia. Compared with that produced by induction of host mesenchymal cells, the amount of bone was insignificant and hardly appreciable. The fate of the bulk of the transplanted cartilage was resorption. After transplantation, germinal chondrocytes resorb, degrade and mobilise the proteinous substances of intercellular matrix; macrophages and multinucleated giant cells supplement the histolytic action of the chondrocytes and remove remnants of cartilage matrix. The multinucleated cells in contact with cartilage matrix (either calcified or uncalcified) are often named chondroclasts. Their origins, however, are generally considered to be the same as those of osteoclasts and foreign-body giant cells-that is, from fusion of mesenchymal cells.

Identified by their capacity to proliferate more rapidly and display a higher percentage of ${ }^{3} \mathrm{H}$-thymidine-labelled nuclei than other cells, the forms that enter into an induction system for osteogenesis are termed either mesenchymal cells (Kember 1960) or preosteoblasts (Tonna

VOI. 50 B, NO. 1, FEBRUARY 1968 
and Cronkite 1961, Owen 1965) or osteoprogenitor cells (Young 1963, 1964). When they grow into implants of articular cartilage they differentiate, not only into bone cells, but also into fibrous tissue, cartilage, marrow, lymphoid and fat cells. Thus, as in induction systems in embryonic life, the induced cells adopt not one but several different lines of specialisation (Urist and McLean 1952, Bridges and Pritchard 1958, McLean and Urist 1961, Ray and Sabet 1963).

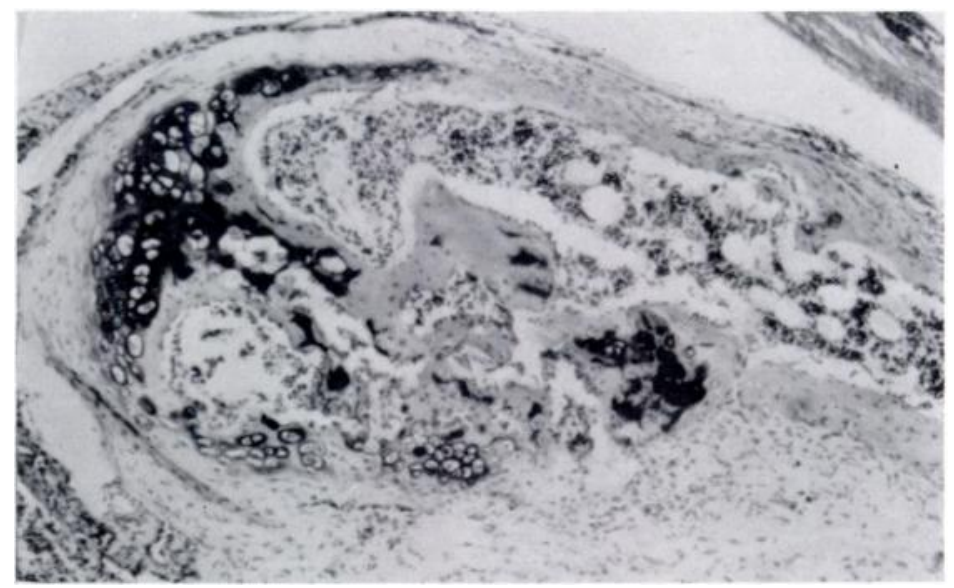

FIG. 18

Photomicrograph of articular cartilage twelve weeks after transplantation, showing ossicle with remnants of unabsorbed articular cartilage, new cancellous bone, bone marrow, and an outer shell of compacta. (Haematoxylin, eosin and azure, $\therefore 500$.)

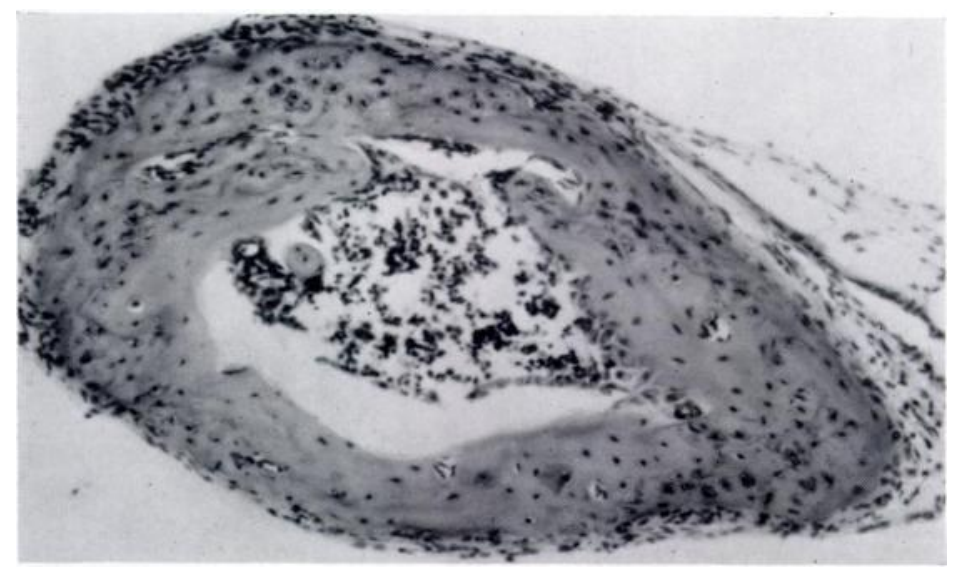

FIG. 19

Photograph of end-product of a transplant of articular cartilage sixteen weeks after the operation showing complete replacement of all of the donor tissue. The end-product is an ossicle composed of compact cortical bone and filled with healthy haematopoietic marrow. (Haematoxylin, eosin and azure, $\times 50$.)

Jacobson (1966) defined embryonic induction as a mechanism of cellular differentiation in which there is interaction between one tissue, the inductor, and another, the responding tissue, as a result of which the responding tissue takes a course of development it would not have followed if the interaction had not occurred. This broad point of view can be used to interpret the results of our experiments with articular cartilage, as well as in our previous work with fracture callus (Urist and colleagues 1965), injured muscle (Selle and Urist 1961, Zaccalini and Urist 1964), and dead, decalcified dentine (Urist, Silverman, Buring, Dubuc and Rosenberg 
1967), or bone matrix (Urist 1965, van de Putte and Urist 1966). When the tissue includes cells that survive and resorb matrix of cartilage, the host cells are induced to form bone within three weeks or less. When the system does not contain living cells of the donor, and depends entirely upon the ingrowth of leucocytes, wandering histiocytes, giant cells and proliferating capillaries of the host, osteogenesis may also be induced, but only after a latent period of four to twelve weeks after the operation. When bone induction appears early after chondrolysis by living

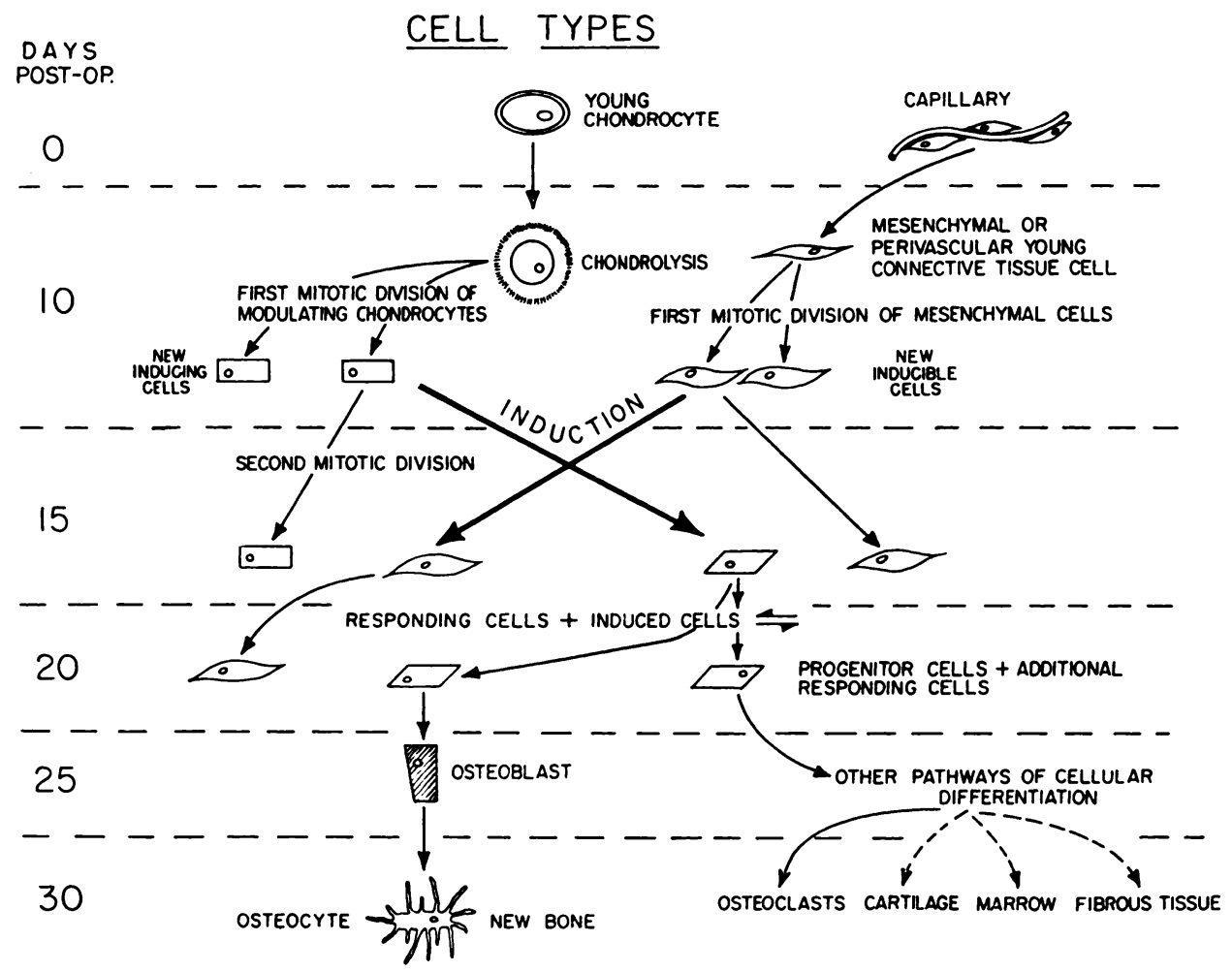

Fig. 20

Diagrammatic representation of ordered sequence of events in the induction system for bone from articular cartilage. During the first ten days after transplantation the germinal cells of articular cartilage lyse the intercellular substance and divide mitotically to produce inducing cells. Swarming occurs during the period between ten and fifteen days and a large number of ingrowing perivascular inducible connective tissue cells of the host interacts with a relatively small number of progeny of donor cells. During the period between fifteen and twenty days the donor tissue contains excavation chambers filled with sprouting capillaries, and proliferating young connective tissue cells. Microscopically, the progeny of the donor and the host are identical, but functionally they are different in so far as some have been induced to differentiate or specialise as osteoblasts, chondroblasts, or haematocytoblasts, or fibroblasts. Some divide and produce more responding or undifferentiated connective tissue cells. Between twenty and twenty-five days the induced cells differentiate into osteoblasts, and between twenty-five and thirty days the new bone containing osteocytes is deposited in one location while new marrow fibrous tissue and cartilage is deposited in another. Osteoclasts appeared only in association with bone tissue and with the onset of remodelling of the initial deposits.

cartilage cells, the yield is large. When the implant is dead and bone induction is delayed, the yield is scanty. Delayed induction may occur also only as a surface reaction with no chondrolysis, and may produce only cartilage as the end-product.

A series of mitotic divisions of the cells of the host bed is necessary in a well ordered sequence to bring about a series of cumulative changes in the developmental programme of mesenchymal cells. Jacobson (1966) suggested that induction is predetermined, beginning with oogenesis; there is no moment or trigger of induction; it is the sum of all past induction and always leads to the development of several cell types (fibrous tissue, fat, marrow, etc.), as well as bone. The cell sequences for bone induction beginning with acellular decalcified 
bone matrix is described in a previous communication (Urist 1965). A diagram of the cell sequences for bone induction by living articular cartilage, beginning with viable chondrocytes, is shown in Figure 20. Interaction of chondrocytes, derived from the germinal layer and connective tissue cells, associated with sprouting capillaries, induced differentiation of osteoblasts. Except that the process is closely related to the surfaces of viable cells, and that resorption of the fibrous proteins of the matrix of bone (Urist 1965, Urist and colleagues 1965, van de Putte and Urist 1966, Urist and Silverman 1966) or dentine (Urist and colleagues 1966) and cartilage may mobilise the inducer, the essential biochemical factors are obscure. Whether new concepts of cell molecular biology can be applied to the problem, as suggested by Watson (1965), remains to be determined by experimental work with immunochemical, ultrastructural and other special methods.

\section{SUMMARY}

1. Isografts of articular cartilage of young rats, with mucoproteins labelled with ${ }^{35} \mathrm{~S}$, extracellular fibrous proteins labelled with ${ }^{3} \mathrm{H}$-glycine, and nuclei labelled with ${ }^{3} \mathrm{H}$-thymidine, were transplanted into the anterior chamber of the eye.

2. Thin split-thickness transplants of the cells of the gliding surface of immature articular cartilage induced the formation of fibrous tissue.

3. Thick transplants and subsurface slices of immature articular cartilage, containing germinal cells of the epiphysial cartilage, induced the formation of new bone consistently within 4 weeks. 4. Full-thickness transplants in articular cartilage from senile rats induced only the formation of fibrous tissue.

5. Slices of growing cartilage, devitalised by cryolysis, or extraction of acid-soluble proteins, produced scanty deposits of bone or cartilage, or both, but only infrequently and generally after a lag phase extending from six to twelve weeks.

6. Reduction in the amount of mucoprotein in the cartilage matrix by papain, and suppression of the resynthesis of tissue proteins by cortisone, retarded but did not prevent bone induction.

7. Bone induction is the product of a series of interactions between inducing cells and responding cells by intracellular and intercellular reactions too complex to characterise in physico-chemical terms at this time.

These investigations were supported by grants-in-aid from the Easter Seal Foundation, Society for Crippled Children and Adults, National Institutes of Dental Research, USPHS, NIH (No. DE-02103-01), Ayerst Laboratories, Inc., Orthopedic Research and Education Foundation, Southern California Chapter of the Arthritis and Rheumatism Foundation, and contracts between the University of California and the U.S. Army (DA-49-193 MD 2556), The Atomic Energy Commission (AT-11-1)-34, Office of Naval Research [NonR 233 (74)]. Thompson Adams was a medical student research fellow from 1962 to 1965, supported by the Alfred Blalock Foundation.

\section{REFERENCES}

Bridges, J. B., and Pritchard, J. J. (1958): Bone and Cartilage Induction in the Rabbit. Journal of Anatomy, 92, 28.

DePalma, A. F., SAwYer, B., and Hoffman, J. D. (1962): Fate of Osteochondral Grafts. Clinical Orthopaedics, 22, 217.

JaCoBson, A. G. (1966): Inductive Processes in Embryonic Development. Science, 152, 25.

KaWiaK, J., MoskalewSKi, S., and DarzYNkiewicz, Z. (1965): Isolation of Chondrocytes from Calf Cartilage. Experimental Cell Research, 39, 59.

Kember, N. F. (1960): Cell Division in Endochondral Ossification. Journal of Bone and Joint Surgery, 42-B, 824.

LACROIX, P. (1947): Organizers and the Growth of Bone. Journal of Bone and Joint Surgery, 29, 292.

McLean, F. C., and URIST, M. R. (1961): Bone. Second edition. Chicago and London: University of Chicago Press.

MankIN, H. J. (1962a): Localization of Tritiated Thymidine in Articular Cartilage of Rabbits. I. Growth In Immature Cartilage. Journal of Bone and Joint Surgery, 44-A, 682.

MankIN, H. J. (1962b): Localization of Tritiated Thymidine in Articular Cartilage of Rabbits. II. Repair In Immature Cartilage. Journal of Bone and Joint Surgery, 44-A, 688.

MankIN, H. J. (1963): Localization of Tritiated Thymidine in Articular Cartilage in Rabbits. III. Mature Articular Cartilage. Journal of Bone and Joint Surgery, 45-A, 529. 
Mankin, H. J. (1964a): Mitosis in Articular Cartilage of Immature Rabbits. Clinical Orthopaedics and Related Research, 34, 170.

Mankin, H. J. (1964b): Osteogenesis in the Subchondral Bone of Rabbits. Journal of Bone and Joint Surgery, 46-A, 1253.

Owen, M. (1965): Cell Differentiation in Bone. In Proceedings of the 2nd European Symposium on Calcified Tissues, pp. 11-22. Edited by L. J. Richelle and M. J. Dallemagne. Liége: Collection des Coloques de l'Université de Liége.

RAY, R. D., and SABET, T. Y. (1963): Bone Grafts: Cellular Survival Versus Induction. Journal of Bone and Joint Surgery, 45-A, 337.

Selle, R. W., and URIST, M. R. (1961): Calcium Deposits and New Bone Formation in Muscle in Rabbits. Journal of Surgical Research, 1, 132.

Tonna, E. A., and Cronkite, E. P. (1961): Cellular Response to Fracture Studied with Tritiated Thymidine. Journal of Bone and Joint Surgery, 43-A, 352.

UrIST, M. R. (1965): Bone: Formation by Autoinduction. Science, 150, 893.

Urist, M. R., and McLean, F. C. (1952): Osteogenetic Potency and New-Bone Formation by Induction in Transplants to the Anterior Chamber of the Eye. Journal of Bone and Joint Surgery, 34-A, 443.

Urist, M. R., Silverman, B. F., Buring, K., Dubuc, F. L., and Rosenberg, J. M. (1967): Clinical Orthopaedics and Related Research, Vol. 53, 243.

Urist, M. R., Wallace, T. H., and Adams, T. (1965): The Function of Fibrocartilaginous Fracture Callus. Journal of Bone and Joint Surgery, 47-B, 304.

van de PutTe, K. A., and URIST, M. R. (1965): Experimental Mineralization of Collagen Sponge and Decalcified Bone. Clinical Orthopaedics and Related Research, 40, 48.

van de PutTe, K. A., and URIST, M. R. (1966): Osteogenesis in the Interior of Intramuscular Implants of Decalcified Bone Matrix. Clinical Orthopaedics and Related Research, 43, 257.

Watson, J. D. (1965): Molecular Biology of the Gene. New York: W. Benjamin Co.

Young, R. W. (1963): Histophysical Studies on Bone Cells and Bone Resorption. In Mechanisms of Hard Tissue Destruction, Publication No. 75, pp. 471-496. Edited by R. F. Sognnaes. Washington, D.C.: American Association for the Advancement of Science.

Young, R. W. (1964): Specialization of Bone Cells. In Bone Biodynamics. Edited by H. M. Frost. Boston, Mass.: Little, Brown and Little.

Zaccalini, P. S., and URIST, M. R. (1964): Traumatic Periosteal Proliferations in Rabbits. The Enigma of Experimental Myositis Ossificans Traumatica. Journal of Trauma, 4, 344. 